\title{
Introduction
}

\section{THE COURSE OF THE ARGUMENT}

This book examines whether, when, and why the antitrust authorities ${ }^{1}$ of the United States of America and European Union have enforced Section 2 of the Sherman $\mathrm{Act}^{2}$ and Article 102 of the TFEU ${ }^{3}$ in order to shape

1 In the United States, antitrust law is primarily enforced by federal judges. Actually, two public bodies are also entrusted with its application: the Antitrust Division of the Department of Justice and the Federal Trade Commission (FTC). The former influences competition law by making speeches, negotiating settlements, and issuing guidelines; the latter enjoys administrative adjudicatory powers. Yet, by and large, they both act as prosecutors rather than as decision-makers: in the end, what they can do is to bring antitrust actions before ordinary federal courts. In contrast, EU competition law is primarily applied by the European Commission, which is an administrative and political body, whose decisions can be challenged in the Court of First Instance (CFI) and in the European Court of Justice (ECJ). In fact, even national competition authorities and national judges can enforce EU competition law but, in order to guarantee a uniform and harmonized enforcing structure, their action is to some extent subject to that of the Commission. See, in this regard, Commission Notice on cooperation within the Network of Competition Authorities - OJ 2004, C101/43 and Commission Notice on the cooperation between the Commission and the courts of the EU Member States in the application of Articles 101 and 102 TFEU - OJ 2004, C101/54. In sum, given the differences between the US and EU enforcing systems, the choice to use hereinafter the generic term 'antitrust (or competition) authorities' to address who is entrusted with the duty to apply competition law in the two jurisdictions could appear superficial and improper. Yet, it helps to simplify the written exposition, and the book will, however, distinguish between US and EU enforcing authorities when the outcomes of its analysis rest with the prerogatives and skills that they enjoy.

2 US Code, Title 15, Chapter 1, available at http://www.law.cornell.edu/uscode/. Section 2 establishes that, 'Every person who shall monopolize, or attempt to monopolize, or combine or conspire with any other person or persons, to monopolize any part of the trade or commerce among the several States, or with foreign nations, shall be deemed guilty of a felony, and, on conviction thereof, shall be punished by fine not exceeding $\$ 100,000,000$ if a corporation, or, if any other person, $\$ 1,000,000$, or by imprisonment not exceeding 10 years, or by both said punishments, in the discretion of the court'.

3 Because of the Treaty of Lisbon - OJ 2007, C306/1 - the European provision regarding the 'abuse of dominant position' changed from article $82 \mathrm{TEC}$ to article $102 \mathrm{TFEU}$. 'TEC' is the acronym for the past Treaty on the European Community - OJ 2002, C325/33. 'TFEU' is the acronym for the actual Treaty on the Functioning of the European Union - OJ 2008, C115/1. Indeed, with the Treaty of Lisbon, the latter has substituted the former. Article 102 states that, "Any abuse by one or more undertakings of a dominant position within the internal market or in a substantial part of it shall be prohibited as incompatible with the internal market in so far as it may affect trade between Member States. Such abuse may, in particular, consist of: (a) directly or indirectly imposing unfair purchase or selling prices or 
the scope of dominant firms' IPRs, such as patents and copyrights. ${ }^{4}$ This research question leads to two inquiries.

On the one hand, since one can expect that such enforcement actions assume the existence of an ideal yardstick to measure the proper scope of dominant firms' IPRs, Chapter 1 clarifies that, from a general perspective, that is to say, without a case-by-case analysis, even economic theory ${ }^{5}$ cannot establish conclusively how broad the scope of dominant firms' patents and copyrights must be.

On the other hand, since Section 2 and Article 102 are the 'tangible tools' that courts and administrative bodies must employ to carry out such enforcement actions, Chapter 2 discusses how, over the years, US and EU antitrust authorities have interpreted the two provisions, establishing their aims and enforcing criteria.

The will to protect competition and innovation or, to put it in another way, the will to protect consumer welfare over the short and long run, ${ }^{6}$ is one of the threads that links these two chapters. ${ }^{7}$ Indeed, Chapter 1 explains that social planners would like to establish the scope of market dominance, patents, and copyrights in order to promote competition and innovation. Chapter 2 observes that, nowadays, antitrust authorities would like to employ Section 2 and Article 102 in order to prohibit dominant firms' practices that strengthen market power and harm competition and innovation. Together, the two chapters show that what should motivate US and EU enforcement actions that are aimed at shaping the scope of monopolists' IPRs is the protection of competition and innovation.

other unfair trading conditions; (b) limiting production, markets or technical development to the prejudice of consumers; (c) applying dissimilar conditions to equivalent transactions with other trading parties, thereby placing them at a competitive disadvantage; (d) making the conclusion of contracts subject to acceptance by the other parties of supplementary obligations which, by their nature or according to commercial usage, have no connection with the subject of such contracts.'.

4 Hereinafter, the book uses the acronym 'IPRs' for intellectual property rights and the terms 'monopolists' and 'dominant firms' as synonyms.

5 The choice to look at what the economic theory teaches as to the scope of dominant firms' IPRs is not accidental. As Chapter 1 shows, economics moulds competition law and contributes to justify the rationale of patents and copyrights.

6 Indeed, Chapter 1 explains that there is a theoretical relationship between the everyday notions of competition and innovation, on the one hand, and the technical economic concepts of short- and long-run consumer welfare, on the other hand.

7 There are other threads between Chapters 1 and 2. For instance, Chapter 1 shows that, away from perfect competition, it is up to policy makers to fix the objectives of competition law and the main features of its enforcing system; Chapter 2 discusses the many policy and enforcing objectives that, over time, Section 2 and Article 102 have pursued. Chapter 1 explains that economic theories cannot establish directly how long market monopolies should last in order to promote competition and innovation; Chapter 2 remarks that the legal standards that antitrust authorities elaborate to assess dominant firms' conduct and thus establish indirectly the proper duration of market monopolies follow from specific policy choices. 
Chapters 3 to 6 test this conclusion from economic and legal standpoints. They describe certain economic models that explain that monopolists may harm consumer welfare by engaging specific behaviors that are expressly authorized by applicable IP systems, and they describe the cases in which US and EU antitrust authorities have enforced Section 2 or Article 102 against these IP-consistent behaviors. ${ }^{8}$ More exactly, these chapters assess, in economic and legal terms, dominant firms: ${ }^{9}$

(i) developing and/or acquiring patentable inventions and copyrightable creative works (see Chapters 3 and 4);

(ii) refusing to license their own IPRs to third parties (see Chapter 5); and

(iii) bringing infringement lawsuits and other IP administrative actions against their actual and potential rivals (see Chapter 6). ${ }^{10}$

Therefore, Chapters 3 to 6 analyze both whether economics can establish, at least from a case-by-case perspective, how broad the scope of dominant firms' IPRs should be, and whether the US and EU legal standards that anti-

8 In this light, therefore, the book's analysis has a backward look: it focuses on past US and EU case law.

9 The book does not analyze whether and when IPRs as such grant monopoly power, though it must be recognized that it happens rarely since there is no 'one-to-one' relationship among IPRs, products, and relevant markets. See, e.g., Robert P. Merges, Intellectual Property Rights and the New Institutional Economics,53 VAND. L. Rev. 1857 (2000); and Frank H. Easterbrook, Intellectual Property is still Property, 13 Harv. J. L. Pub. Pol. 1 (1990). Indeed, at least in applying Section 2 and Article 102, antitrust authorities have never presumed market power to arise from patents and copyrights. See, on the US side, United States v. E. I. du Pont de Nemours \& Co., 351 U.S. 377 (1956); and United States v. Loew's, Inc., 371 U.S. 38 (1962); and, on the EU side, Case 24/67, Parke, Davis and Co. v Probel, Reese, BeintemaInterpharm and Centrafarm, February 29 1968, [1968] ECR 55, and Case 78/70 Deutsche Grammophon Gesselschaft mbH v Metro-SB-Großmärkte GmbH \& Co. KG., June 8 1971, [1971] ECR 487.

10 The behaviors that the book chooses to analyze are unlikely to cover all the monopolistic practices involving IPRs. Rather they have a peculiar heuristic value as to US and EU antitrust attitudes towards both dominant firms' conduct and the interface between competition and IP laws. On the one hand, the behaviors in question call for a clear definition of what antitrust authorities should prohibit via Section 2 and Article 102 because, although they may contribute to strengthen monopolists' market power, they do not always harm consumer welfare, even when they serve to realize predation, entry-deterrence, or leverage. On the other hand, these behaviors lie at the very heart of IP laws by consisting of the enforcement of some of the quintessential prerogatives that IPR holders (or would-be IPR holders) boast. Therefore, to analyze how these behaviors do violate antitrust laws means, first, setting up the case for a conflict between antitrust provisions and IP rules. Then it entails acknowledging that an antitrust intervention aimed at striking those practices curbs IPRs prerogatives and, hence, reduces the scope of IPRs as though antitrust authorities could act as second-tier regulators. Third, analyzing these behaviors allows discussing how the two jurisdictions' antitrust authorities have managed this legal conflict, trying to find out whether, when and why they applied different legal standards and make antitrust law prevail over IP laws or vice versa. 
trust authorities have applied in their case law are responsive to what economic models suggest as to the protection of competition and innovation.

This compound inquiry - which also deals with the confrontation between the antitrust and the IP worlds - allows the reader to consider several other topics. They all deal with the differences that distinguish the US and EU jurisdictions, and can be easily summarized with one simple question: why do US and EU antitrust authorities follow different approaches in shaping the scope of patents and copyrights that dominant firms hold?

The Conclusion explores the policy issues that contribute to the answer to this question, and explains the convergences and divergences between the two jurisdictions. Notwithstanding the role that economics plays in fashioning antitrust (or competition) law and in justifying the rationale of patents and copyrights, the book shows that non-economic principles can explain whether, when, and why antitrust authorities apply Section 2 and Article 102, in order to shape some dominant firms' IPRs, such as patents and copyrights.

The scheme shown in Figure 0.1 reproduces what is stated above, by portraying diagrammatically the course of the book's argument.

\section{SOME CAVEATS}

According to the legal tradition of civil law countries, a study that intends to deal with the interface between antitrust and IP laws should start by discussing in full detail what scholars have elaborated about the terms of such a comparison, namely, what antitrust law, ${ }^{11}$ IP laws, and their

\footnotetext{
11 Definitions are never expected to be conclusive or exhaustive. Rather, they can work as effective analytical tools aimed at simplifying inquiries, like the definitions regarding the terms that the book will use hereinafter. For instance, the book employs the stricter meaning of the EU expression 'competition law' as a synonym of the US term 'antitrust law', in order to address the rules dealing with anticompetitive agreements and monopolistic conduct, i.e. Sections 1 and 2 of the Sherman Act and Articles 101 and 102 of the TFEU. Actually, the above expressions can also address both the rules concerning merger control, and, in the sole European Union, the provisions that aims to regulate Member States' involvement in business practices. See Section 7 of the Clayton Act (US code, Chapter 1, Title 15, Sections 12 et seq.), Council regulation (EC) No.139/2004, OJ 2004, L24/1, and Article 106 of TFEU. Second, the book makes a distinction between 'antitrust (or competition) law' and 'antitrust (or competition) policy', viewing the former as a branch of the latter. The former addresses the prohibitions concerning specific firms' behaviors. The latter refers to a larger array of rules that: (i) encompasses not only proscriptions but also prescriptions; (ii) addresses not only firms but also governments; and (iii) aims to determine not only the impact that a single firm's practice has on market's outcome and development, but the general level of competition within the borders of one jurisdiction. For instance, the so-called 'competition (or antitrust) policy' also includes the enforcement of antidumping regulation, the scrutiny of public restrictions on entry into
} 
The research question: whether, when and why do US and EU antitrust authorities enforce Section 2 and Article 102, in order to shape the scope of monopolists' patents and copyrights?

Chapter 1: Does economics establish how broad dominant firms' patents and copyrights must be?

- Economic theories suggest that the scope of firms' market dominance, patents, and copyrights has to be established in order to promote competition and innovation.

- There is no ideal economic yardstick for measuring the scope of market monopolies patents, and copyrights.

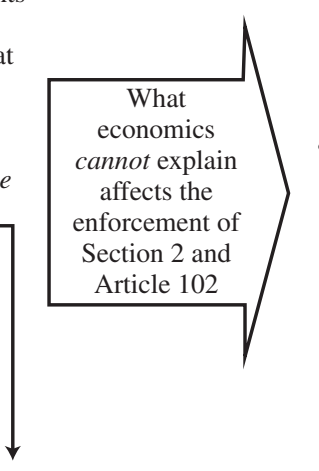


interface are. It should continue by elaborating the general principles that govern such an interface, first indentifying whether and when antitrust and IP laws enter into conflict, and then analyzing whether these conflicts should be solved by making antirust law prevail over IP laws, or vice versa. Finally, it should conclude by stating whether courts and administrative authorities have acted in accordance with these theoretical guidelines.

Yet, such an analysis would not fit well with a comparative examination of the antitrust rules affecting monopolists' behaviors because, both in the United States and in the European Union, competition law stems more from economics, case law, and industrial policies, rather than from articulated pieces of legislation and universal legal principles. Therefore, the book adopts a different approach: by following a more analytical and inductive analysis, it teases out the policy issues that antitrust authorities face in dealing with monopolists' practices involving IPRs.

Without lingering over transatlantic doctrinal debates it is, however, useful to give some definitions as to what antitrust law, IPRs, and their interface are, or, at the very least, are taken to be in this context.

As to antitrust law, it is assumed that this is a set of prohibitions concerning firms' specific behaviors, so that it can be analogized to a surgical intervention adept at excising specific illnesses, rather than to a steady cure aimed at treating a chronic disease. ${ }^{12}$ Hence, competition law should not be considered a tool for forging market structures, the initial distribution of market opportunities, or the early allocation of incentives to compete and innovate. Rather, antitrust law is a means for prosecuting those firms' behaviors that worsen existing markets' performance, ${ }^{13}$ that is to say, those behaviors

a market, the choice to subsidize a specific industry (or a specific firm, as in the case of the European doctrine of state aid), and even suggestions for adjustments in the design of intellectual property systems. See, e.g., Richard Gilbert \& Oliver Williamson, 'Antitrust Policy', in The New Palgrave Dictionary of Economics and the Law 82 (Peter Newman ed. 1988); Andrew I. Gavil, William E. Kovacic, \& Jonathan B. Baker, Antitrust Law in Perspective: Cases, Concepts and Problems in Competition Policy 4 (2008); and Herbert J. Hovenkamp, 'Innovation and the Domain of Competition Policy' 1, University of Iowa Legal Studies Research Paper, Number 08-07, March, 2008 (stating that, "Competition policy' refers to the full range of public rules and sanctions designed to ensure that markets are as competitive as they can realistically be, consistent with these other policies. In the United States the term 'competition policy' certainly includes the antitrust laws as a central component, but competition policy is in fact much broader.'). Third, the term 'policy' when referred to antitrust enforcement can also address the several issues that lie behind prosecuting choices. In other words, it is common to say that whether a specific competition action is worthwhile is a matter of 'policy', meaning a matter that regards the efficient use of the scarce resources available to those who enforce competition law. As the following chapters show, such a question becomes pressing when it turns to the study of the antitrust intervention against dominant firms.

12 For this analogy see Frederic M. Scherer, David Ross, Industrial Market Structure and Economic Performance 12 (1990).

13 As Chapter 2 explains, no antitrust concepts exist in nature: antitrust aims as well 
that, given preliminary firms' endowments, prevent markets' outcomes that should follow from the natural interaction between demand and supply.

As to IPRs, two clarifications are due. ${ }^{14}$ First, in the following discussion IPRs are primarily meant to be ius excludendi alios, without discussing whether this is enough to consider them as property rights. ${ }^{15}$ For the purpose of the arguments developed in this book, indeed, it is enough to consider that IPRs grant to their owners the right to exclude anybody else from using and reproducing them and, hence, the power to decide who to include in their enjoyment. ${ }^{16}$ Secondly, because of the role that economics plays in shaping antitrust law, IPRs are here analyzed from the eco-

as antitrust rules derive from specific policy choices. Therefore, what has been described here as the 'natural interaction between demand and supply' is what society expects to achieve through the operation of market forces. See, e.g., Andrew I. Gavil, William E. Kovacic, Jonathan B. Baker, Antitrust Law in Perspective: Cases, Concepts and Problems in Competition Policy 16 (2008); Carl Kaysen, Donald F. Turner, Antitrust Policy; An Economic And Legal Analysis 14 (1959).

14 For a general discussion of what IPRs are, see, e.g., David I. Bainbridge, Intellectual Property (2007); Adam D. Moore, Intellectual Property \& Information Control. Philosophic Foundations and Contemporary Issues (2001); William R. Cornish \& David Llewelyn, Intellectual Property: Patents, Copyrights, Trademarks and Allied Rights (1999); Lawrence C. Becker, 'Deserving to Own Intellectual Property', 68 Chicago-Kent Law Review 609 (1993); Michael Lehmann, 'The Theory of Property Rights and the Protection of Intellectual and Industrial Property', 16 International Review of Industrial Property and Copyright Law 525 (1985).

15 In other words, the book does not discuss what the right of property is, for instance whether it should be viewed as either 'a bundle of rights', or 'the right to exclude others from the use of its subject matter'; or 'the unrestricted right of using, enjoying and disposing of its subject matter'. For the first theory see, e.g., Wesley Newcomb Hohfeld, 'Fundamental Legal Conceptions as Applied in Judicial Reasoning', 26 Yale L.J. 710 (1917); and id., 'Some Fundamental Legal Conceptions as Applied in Judicial Reasoning', 23 Yale L.J. 16 (1913) (arguing that property is a set of rights, duties, privileges, powers, liabilities, disabilities, and immunities that courts interpret in disputes). For the second theory see, e.g., Thomas W. Merrill, 'Property and the Right to Exclude', 77 Neb. L. Rev. 730 (1998) (arguing that, 'The right to exclude others is more than just 'one of the most essential constituents of property - it is the sine qua non'); and Richard A. Epstein, Takings, Private Property and the Power of Eminent Domain 65 (1985) (arguing that, 'The idea of property embraces the absolute right to exclude.') The third definition comes directly from the Roman tradition, where property was conceived as jus utendi et abutendi re sua quatenus iuris ratio patitur. A different issue is speaking about the 'propertization' of IPRs. With this expression, indeed, scholars want just to address the fact that recently IP laws have been subject to subsequent reforms, which have not only created new IPRs, included new items in the subject matter of traditional IPRs, but have also enlarged the duration and the scope of traditional IPRs. Therefore, nowadays the prerogatives of IPR holders seem to be 'unlimited' as much as the rights of the holders of traditional property rights. Yet, though they are said to be 'absolute', even traditional property rights suffer some limitations, as well as several IP doctrines work as 'antibodies' against the on-going enlargement of IPRs. See Gustavo Ghidini, Intellectual Property and Competition Law (2006), and Michael A. Carrier, 'Cabining Intellectual Property through a Property Paradigm', 54 Duke L.J. 1, 4-7 (2004).

16 See Ghidini, supra note 15 . To be sure, IPRs can be conceptualized according to different theories. For instance, see Ilkka Rahnasto, Intellectual Property Rights, External Effects and Antitrust Law 49 (2002). 
nomic perspective, that is to say, by deeming them as tools for promoting efficiency, technological and cultural innovation. Yet, it is worth to recall that over the years, political and legal scholars have put forward several non-economic theoretical justifications for explaining the rationale of IPRs $^{17}$ - explanations that, perhaps apart from the theory of natural rights, ${ }^{18}$ can soundly be applied to both US and EU IPRs. For instance,

17 See, e.g., Lionel Bentley \& Brad Sherman, Intellectual Property Law 39 (2009); Edwin C. Hettinger, 'Justifying Intellectual Property', 18 Philosophy and Public Affairs 31, 37 (1989).

18 Natural law views property rights as arising out of the logic of nature and, as such, independent from any specific kind of civil society. See generally David Hume, A Treatise of Human Nature (1740); and John Locke, Second Treatise of Government (1690). According to the natural rights theory, therefore, patents and copyrights flow from the fundamental, inalienable, and undeniable rights that humans have by virtue of what they are, such as the (moral) right to 'have one's own identity connected to one's own creations and inventions'. Ideas must belong to their creators because they are the manifestation of their creators' personalities. See, e.g., Wendy J. Gordon, 'A Property Right in Self-Expression: 'Equality and Individualism in the Natural Law of Intellectual Property', 102 Yale L. J. 1533 (1993); Tom G. Palmer, 'Are Patents and Copyrights Morally Justified?', 13 Harvard Journal of Law and Public Policy 817 (1990); Alfred C. Yen, 'Restoring the Natural Law: Copyright as Labor and Possession', 91 Ohio St. L. J. 517 (1990). Further, consider that Art. 27(2) of the Universal Declaration of Human Rights states that 'everyone has the right to the protection of the moral and material interests resulting from any scientific, literary or artistic production of which he is the author'. True, as mentioned in the text, it is often said that on the European continent IP is perceived as having its roots in natural law, while in Anglo-American jurisdictions IP laws have utilitarian foundations. Indeed, the concept of moral rights was specifically rejected by the drafters of the US Constitution, as Thomas Jefferson wrote, 'inventions then cannot, in nature, be a subject of property. Society may give an exclusive right to the profits arising from them, as an encouragement to men to pursue ideas which may produce utilities, but this may or may not be done according to the will and convenience of society, without claim or complaint from anybody' - Walton $\mathrm{H}$. Hamilton, Patents and Free Enterprise. Investigation of Concentration of Economic Power 21 (1941). Nevertheless, this argument cannot be pushed too far: intimations of both natural rights-based and utility-based claims can be found in most countries. See Jane C. Ginsburg, 'A Tale of Two Copyrights: Literary Property in Revolutionary France and America', 64 Tul. L. Rev. 991 (1990); and Justin Hughes, 'The Philosophy of Intellectual Property', 77 Geo. L. J. 287, 288 (1988) (arguing that, 'rights in our society cannot depend for their justification solely upon statutory or constitutional provisions'). Further see e.g. Roberta R. Kwall, 'Copyright and the Moral Right: Is an American Marriage Possible?', 38 Vand. L. Rev. 1, 5-16 (1985) (suggesting the US should converge towards the European law which recognizes moral and personal rights rather than mere pecuniary interests); Michael Katz, 'The Doctrine of Moral Rights and American Copyright Law - A Proposal', 24 S. Cal. L. Rev. 375, 391-409 (1951) (proposing that the US should incorporate the European concept of moral rights into copyright law); and Martin A. Roeder, 'The Doctrine of Moral Rights: A Study in the Law of Artists, Authors and Creators', 53 Harv. L. Rev. 554, 558-65 (1940). Broadly speaking, the natural right approach to IPRs is named 'axiomatic'. It differs from the consequentialist theory according to which the existence of IPRs is to be decided on the consequences that they produce on the whole society. Nevertheless, see Peter Lewin, 'Creativity or Coercion: Alternative Perspectives on Rights to Intellectual Property', 71 Journal of Business Ethics 441 (2007) (claiming that, upon examination, this distinction is misleading and that ultimately all legal-ethical-moral justification schemes have to be based on a consideration of consequences). 
one should not forget that, according to the Lockean theory of labor and property rights, ${ }^{19}$ IPRs derive from the universal right to 'own oneself' and the consequential universal right to 'own the fruits of one's own labor', such as intellectual goods. ${ }^{20}$ Indeed, when one mingles one's efforts with 'the raw stuff of the world', any resulting product ought to be one's own. ${ }^{21}$ Likewise, it is by endorsing the so-called contractarian theory that patents can be described as what governments grant to inventors in exchange for the knowledge that they disclose via the patenting process. ${ }^{22}$ Similarly, from a political standpoint, copyrights have been conceptualized as 'state measures' designed to fortify democracy by promoting the public debate and feeding expressive diversity and pluralism. ${ }^{23}$

Finally, as to the interface between antitrust and IP laws, it can be portrayed in a very simple way, by stating that each firm's practice involving IPRs can be found legal or illegal pursuant to IP provisions, and legal or illegal pursuant to competition rules, so that the four-scenario scheme shown in Table 0.1 is conceivable:

Table 0.1 The Antitrust-IP Interface

\begin{tabular}{|l|ll|}
\hline & IP Law & \\
\hline Competition Law & I & III \\
& Illegal & Legal \\
& Legal & Legal \\
& II & IV \\
& Illegal & Legal \\
& Illegal & Illegal \\
\hline
\end{tabular}

19 For a discussion of two possible interpretations of the Lockean conception of labor i.e. the avoidance theory and the value-added view - see Hughes, supra note 18, at 302-310.

20 See, e.g., Hughes, supra note 18, at 301-302 (arguing that, 'Locke . . begins his justification of property with the premise that initially only our bodies are our property. [. . .] Our handiwork becomes our property because our hands - and the energy, consciousness, and control that fuel their labor - are our property. [. . .] [Therefore, the Author concluded that] Locke linked property to the product of the individual person's labor.').

21 See, e.g., Frank I. Michelman, 'Property, Utility, and Fairness: Comments on the Ethical Foundations of “Just Compensation” Law', 80 Harv. L. Rev. 1165, 1204 (1967).

22 This is the main intuition underpinning the so-called 'consideration doctrine', which - as said in the text - can be led inside the frame of a more general theory, the so-called 'contractarian theory'. According to this theory IPRs exist because they fit into the 'social contract' upon which the whole society has been built up.

23 See, e.g., Neil Weinstock Netanel, 'Copyright and a Democratic Civil Society', 106 Yale L.J. 283, 291 (1996). 
Now, as a matter of logic, it should be noted that a 'legal conflict' happens only when, once the range of action of IP and antitrust rules are understood and fixed, ${ }^{24}$ a dominant firm's practice is legal according to the former (IP) and illegal according to the latter (antitrust), or vice versa. In other words, whereas no issue arises when a dominant firm either complies with or violates both IP and antitrust laws, certain issues of coordination and setting priorities arise when the two bodies of law qualify particular conduct in a conflicting way.

From an antitrust standpoint, which is the one focused upon in this book, the case of conduct that infringes IP provisions but does not violate competition law does not lead to difficulties of enforcement. Indeed, it is hard to conceive of a case in which the EU antitrust authorities (whether communitarian or national), though devoid of interest, would take the initiative to act in lieu of IP national judges when, in addition, they would have no power to act under IP national laws against firms that do not comply with them. ${ }^{25}$ Likewise, it is hard to conceive of a case in which US judges, though they can act to interpret IP law and use it against the illegal behavior, would nonetheless prefer to act against it in the name of an unfounded antitrust claim. In effect, Chapters 3 to 6 show that, perhaps because of the costs that the antitrust enforcement entails, antitrust authorities have not tended to enlarge their jurisdictions to cover behaviors that are antitrustcompliant but not IP consistent. Such behaviors would be handled within the IP realm.

Instead, from the antitrust standpoint, it becomes crucial to understand how to manage the conflict between IP laws and competition provisions when the latter prohibits behavior that the former permits.

The research question beneath the book, indeed, falls within the boundaries of this last 'square' of the Antitrust-IP interface.

24 To be sure, it can be difficult to draw the limits of IPRs' and competition rules' range of action: for instance, as seen in Chapter 2, it is complex to establish limits of dominant firms' liability. Equally, though this book does not face such a topic, it is questionable whether, for instance, some practices represent an IP misuse or fall under those doctrines that establish the exceptions to IP rules. Therefore, not every case is easy to place in one of the four finals cells of the above diagram.

25 Indeed, as Chapter 1 explains, European antitrust authorities have no jurisdiction upon IP issue, because IPRs are mainly a matter of national laws. 
Mariateresa Maggiolino - 9781849809634 Downloaded from PubFactory at 04/26/2023 10:07:17AM via free access 